\title{
Validitas dan Kepraktisan Bahan Ajar Pengelolaan Spesies Asing Invasif Acacia Nilotica untuk Matakuliah Pengelolaan Sumberdaya Alam
}

\author{
Kharirrotun Nafiah ${ }^{1}$, Suhadi $^{1}$, Murni Sapta Sari ${ }^{1}$ \\ ${ }^{1}$ Pendidikan Biologi-Universitas Negeri Malang
}

\section{INFO ARTIKEL}

\section{Riwayat Artikel:}

Diterima: 07-05-2019

Disetujui: 27-05-2019

\section{Kata Kunci:}

validity; practicality; teaching materials; acacia nilotica; validitas; kepraktisan; bahan ajar; acacia nilotica

\section{Alamat Korespondensi}

\section{Kharirrotun Nafiah}

Pendidikan Biologi

Universitas Negeri Malang

Jalan Semarang 5 Malang

E-mail:kharirrotun@gmail.com

Matakuliah Pengelolaan Sumberdaya Alam merupakan salah satu matakuliah wajib untuk mahasiswa S1 Biologi yang mengambil konsentrasi bidang ekologi. Pembelajaran matakuliah tersebut tercantum dalam Rencana Perkuliahan Semester di antaranya memuat capaian pembelajaran dan materi perkuliahan. Capaian pembelajaran salah satunya yaitu mahasiswa mampu menggunakan konsep, prinsip dan prosedur dalam kajian pengelolaan sumberdaya alam, untuk menemukan, menganalisis dan memecahkan permasalahan dengan menerapkan ilmu dan teknologi. Berdasarkan capaian pembelajaran tersebut, dapat diketahui bahwa dengan mengangkat suatu permasalahan kontekstual dalam program pengelolaan sumberdaya alam dapat digunakan untuk membantu mahasiswa dalam proses pembelajaran.

Permasalahan yang ditemui dalam matakuliah pengelolaan sumberdaya alam yaitu jenis dan jumlah bahan ajar yang masih terbatas. Mahasiswa mayoritas menggunakan text book yang didalamnya masih kurang membahas proses pengelolaan sumberdaya alam yang berasal dari Indonesia. Mahasiswa kesulitan mencari referensi pengelolaan sumberdaya alam karena masih sedikit peneliti yang mengembangkannya sehingga diperlukan bahan ajar berdasarkan hasil penelitian untuk matakuliah pengelolaan sumberdaya alam. Bahan ajar yang dikembangkan mengangkat suatu permasalahan kontekstual berkaitan dengan materi perkuliahan yang selanjutnya dapat dibelajarkan kepada mahasiswa.

Bahan ajar memiliki banyak fungsi, di antaranya dapat dipakai untuk meningkatkan pengetahuan dan pengalaman (Izzati et al., 2013), hasil belajar kognitif (Pratiwi et al., 2014), memperbaiki kualitas dan keefektifan pembelajaran (Gazali, 2016). Salah satu materi yang terdapat pada perkuliahan yaitu pengelolaan spesies asing. Spesies asing mampu menyebabkan masalah besar bagi ekosistem karena berpotensi invasif. Spesies asing invasif yang berdampak negatif bagi ekosistem dapat ditemukan di Taman Nasional Baluran. Acacia Nilotica merupakan spesies asing invasif Taman Nasional Baluran yang pertama kali diintroduksi untuk mencegah kebakaran savana karena sifatnya yang tahan terdapat kebakaran. Acacia Nilotica yang awalnya 
digunakan sebagai sekat kebakaran selanjutnya dengan cepat mampu menginvasi savana Bekol (Caesariantika et al., 2011; Djufri, 2012; Sutomo \& Etten, 2017). Acacia Nilotica saat ini telah menginvasi >50\% total savana Baluran (Djufri et al., 2012; Wahyudi et al., 2016; Muhammad \& Utomo, 2018). Materi spesies asing invasif dapat diajarkan dengan problem based learning karena permasalahan Acacia Nilotica menyebabkan berbagai permasalahan bagi lingkungan yang cocok dengan pembelajaran berbasis masalah.

Bahan ajar berbasis PBL dapat digunakan untuk membelajarkan materi dan konsep yang ada kaitannya dengan permasalahan yang berasal dari lingkungan sekitar (Lewinshon et al, 2014), sehingga mahasiswa dapat aktif dalam membangun pengetahuan melalui permasalahan yang terjadi secara kontekstual (Hartati, 2016). Bahan ajar berbasis masalah memiliki banyak keunggulan. Keunggulan bahan ajar berbasis PBL yaitu membangun kompetensi sosial dan personal (Euler \& Kuhler, 2017), merangsang ketertarikan mahasiswa terhadap isu ilmiah dan mendorong tanggungjawab pada lingkungan (Wulandari \& Sholihin, 2015). Pengembangan bahan ajar mengacu pada model pengembangan ADDIE (Branch, 2009). Keuntungan menggunakan ADDIE yaitu efektif untuk membuat perangkat pembelajaran (Moradmand et al., 2014) dan memiliki langkah sistematis untuk mengembangkan produk dalam pembelajaran (Yusuf et al., 2017).

\section{METODE}

Penelitian merupakan penelitian pengembangan yang menggunakan model ADDIE (Branch, 2009). Penelitian menghasilkan produk berupa bahan ajar untuk mahasiswa. Bahan ajar yang dikembangkan berbasis masalah pada materi pengelolaan spesies asing invasif. Waktu penelitian dimulai April-Agustus 2019. Penelitian dilakukan di Taman Nasional Baluran dan Universitas Negeri Malang. Penelitian lapangan yang dilakukan adalah memetakan persebaran Acacia nilotica di savana Bekol Taman Nasional Baluran, analisis vegetasi, dan pengukuran faktor abiotik. Uji validitas dan kepraktisan bahan ajar dilakukan di Universitas.

\section{Analisis/Analyze}

Tahap analisis dilakukan dengan melakukan identifikasi permasalahan yang terjadi dalam suatu matakuliah, kondisi ideal yang diharapkan dan cara yang dapat dilakukan untuk memperbaiki kualitas pembelajaran. Analisis kebutuhan difokuskan pada penggunaan bahan ajar oleh mahasiswa. Analisis kebutuhan dilakukan dengan observasi matakuliah Pengelolaan Sumberdaya Alam, wawancara dengan pengampu matakuliah dan penyebaran angket kepada mahasiswa. Hasil analisis kebutuhan, meliputi (a) mengetahui jenis bahan ajar matakuliah Pengelolaan Sumberdaya Alam, (b) mengetahui kelemahan dari bahan ajar yang digunakan, (c) mengetahui permasalahan pemahaman materi oleh mahasiswa, dan (d) menentukan jenis materi yang dijadikan pengembangan bahan ajar.

Hasil analisis kebutuhan, meliputi (a) bahan ajar yang digunakan oleh sebagian besar mahasiswa adalah text book dan masih sedikit yang menggunakan jurnal, (b) kelemahan bahan ajar yang digunakan yaitu sebagian besar belum menggunakan hasil penelitian dari permasalahan yang terjadi secara kontekstual, (c) materi yang dibahas pada matakuliah masih kurang mendalam, dan (d) materi pengelolaan spesies asing invasif hanya sedikit dibahas dalam matakuliah sehingga mahasiswa kurang begitu memahami yang dimaksud dengan spesies asing invasif dan cara pengelolaannya. Berdasarkan hal tersebut, maka dikembangkan bahan ajar berbasis PBL materi pengelolaan spesies asing invasif yang dicontohkan berdasarkan hasil penelitian pengelolaan Acacia Nilotica yang dikaji secara mendalam.

\section{Merancang/Design}

Bahan ajar dirancang seluruh komponennya agar tujuan pengembangan bahan ajar dapat tercapai. Kerangka bahan ajar, meliputi cover, pendahuluan, isi (capaian, tujuan pembelajaran, materi inti, rangkuman, contoh soal dan cara menjawab), penutup, glosarium, daftar rujukan dan lembar kerja. Instrumen validasi yang dirancang yaitu instrumen validasi ahli materi, media, praktisi, dan uji coba pada mahasiswa.

\section{Mengembangkan/Develop}

Tahap mengembangkan merupakan lanjutan dari tahap merancang. Komponen bahan ajar yang sudah dirancang selanjutnya dikembangkan sesuai dengan materi yang diangkat dalam bahan ajar. Konten bahan ajar berupa Acacia Nilotica yang menginvasi Taman Nasional Baluran, meliputi taksonomi, deskripsi, distribusi, iklim, siklus hidup, introduksi di Baluran, proses invasi, persebaran, pemetaan, manfaat, dampak dan pengelolaannya. Media yang dipakai untuk mendukung bahan ajar adalah Microsoft Office Word 2007 untuk menyusun bahan ajar, ARCGIS 10.2 untuk membuat peta wilayah, dan Corel Draw X6 untuk mendesain cover dan isi bahan ajar. Panduan yang dibuat untuk bahan ajar yaitu panduan untuk dosen dan panduan untuk mahasiswa yang meliputi petunjuk belajar menggunakan bahan ajar, petunjuk mengerjakan lembar kerja dan petunjuk mengerjakan soal pretest dan postest.

Instrumen yang dikembangkan untuk digunakan dalam penilaian bahan ajar, meliputi validasi dari ahli materi, media dan pengembangan dan kepraktisan dari praktisi lapangan. Uji validitas dari ahli materi dinilai berdasarkan aspek relevansi materi, keakuratan materi, kelengkapan sajian, sistematika sajian, kesesuaian sajian, cara penyajian, kesesuaian dengan kaidah bahasa Indonesia, dan kekomunikatifan. Uji validitas dari ahli media dan pengembangan bahan ajar aspek yang dinilai, meliputi 
kelayakan isi, kebahasaan, sajian dan kegrafisan. Kepraktisan bahan ajar dinilai oleh praktisi lapangan meliputi aspek kelayakan isi, ketercapaian tujuan, format, kebahasaan dan kegrafisan. Bahan ajar diuji coba terbatas pada 10 orang mahasiswa yang hasilnya dimasukkan sebagai kepraktisan bahan ajar.

\section{Evaluasi/Evaluate}

Tahap evaluasi merupakan proses untuk melihat ketercapaian bahan ajar. Tahap evaluasi dilakukan pada setiap tahapan pengembangan yang disebut evaluasi formatif untuk kebutuhan revisi. Revisi bahan ajar didasarkan pada nilai, komentar, kritik dan saran dari dari validator ahli materi, media dan praktisi lapangan yang selanjutnya digunakan untuk melakukan perbaikan demi kesempurnaan bahan ajar yang telah dikembangkan dan kriteria mengadaptasi dari Akbar (2013).

\section{HASIL}

Bahan ajar divalidasi oleh ahli materi yaitu dosen Biologi Universitas Negeri Malang yang memiliki pengalaman dalam mengajar dan penelitian terkait spesies asing invasif selama lebih dari 10 tahun. Data yang diperoleh dari ahli materi berupa nilai, komentar dan saran untuk bahan ajar. Saran yang diberikan oleh ahli materi, meliputi (1) menambahkan asal kata spesies asing invasif dari berbagai sudut pandang, (2) penjelasan gambar persebaran spesies asing invasif melalui peta persebaran harus lebih detail, (3) penjelasan mekanisme invasi spesies asing dapat dipecah menjadi dua bagian, yaitu secara langsung dan tidak langsung, dan (4) menambahkan saran dari peneliti terkait pengelolaan Acacia Nilotica. Hasil validitas bahan ajar yang diberikan oleh validator ahli adalah 95,58\% yang berarti bahan ajar sangat valid dan memerlukan revisi kecil. Hasil uji validitas bahan ajar yang diperoleh ahli materi yang ditunjukkan pada tabel 1.

Tabel 1. Validitas Materi Bahan Ajar

\begin{tabular}{lcc}
\hline \multicolumn{1}{c}{ Penilaian Aspek } & Perolehan Skor & Skor Tertinggi \\
\hline Relevansi Materi & 36 & 36 \\
\hline Keakuratan Materi & 16 & 16 \\
\hline Kelengkapan Sajian & 14 & 16 \\
\hline Sistematika Sajian & 3 & 4 \\
\hline Kesesuaian Sajian & 20 & 20 \\
\hline Cara Penyajian & 14 & 16 \\
\hline Kesesuaian dengan KBBI & 11 & 12 \\
\hline Keterbacaan dan Kekomunikatifan & 16 & 16 \\
\hline \multicolumn{1}{c}{ Total Skor } & 130 & 136 \\
\hline \multicolumn{1}{c}{ Persentase } & \multicolumn{2}{c}{$95,58 \%$} \\
\hline
\end{tabular}

Validator pengembangan bahan ajar adalah dosen Pascasarjana Biologi UM yang berpengalaman terkait pengembangan media dan memiliki kualifikasi pendidikan Doktor. Penilaian yang diberikan validator ahli media adalah 90,52\% yang berarti bahan ajar sangat valid dan memerlukan revisi kecil. Saran dan komentar yang diberikan (1) huruf pada judul dan subjudul harus dibedakan warnanya, (2) penggunaan kata kerja operasional penting dan harus digunakan dalam tujuan pembelajaran, (3) perlu ditambahkan daftar gambar, daftar tabel, (4) perlu ditambahkan penomoran tabel dan gambar di setiap bab, (5) sintaks PBL dapat langsung dimasukkan dalam setiap Bab, dan (6) dalam kata pengantar perlu dijelaskan bahwa bahan ajar merupakan hasil dari penelitian. Hasil uji validitas bahan ajar dari ahli media dan pengembangan secara lengkap ditunjukkan pada tabel 2.

Tabel 2. Validitas Media dan Pengembangan Bahan Ajar

\begin{tabular}{lcc}
\hline Penilaian Aspek & Perolehan Skor & Skor Tertinggi \\
\hline Kelayakan Isi & 27 & 30 \\
\hline Kebahasaan & 19 & 20 \\
\hline Sajian & 23 & 25 \\
\hline Kegrafisan & 17 & 20 \\
\hline \multicolumn{1}{c}{ Total Skor } & 86 & 95 \\
\hline \multicolumn{1}{c}{ Persentase } & \multicolumn{2}{c}{$90,52 \%$} \\
\hline
\end{tabular}

Praktisi lapangan yang melakukan penilaian bahan ajar adalah dosen pengampu matakuliah Pengelolaan Sumberdaya Alam. Nilai yang diberikan praktisi lapangan terhadap bahan ajar sebesar $89,58 \%$. Hal ini berarti bahan ajar sangat praktis untuk digunakan, namun perlu dilakukan revisi kecil. Saran dan komentar dari praktisi lapangan (1) soal yang terdapat di dalam bahan ajar diperbaiki ke dalam tingkatan analisis dan (2) materi dapat ditambahkan dari jurnal penelitian untuk memperkaya materi bahan ajar. Hasil uji kepraktisan bahan ajar dari praktisi lapangan ditunjukkan pada tabel 3 . 
Tabel 3. Kepraktisan oleh Praktisi Lapangan

\begin{tabular}{lcc}
\hline \multicolumn{1}{c}{ Penilaian Aspek } & Perolehan Skor & Skor Tertinggi \\
\hline Kelayakan Isi & 19 & 20 \\
\hline Ketercapaian Tujuan & 30 & 32 \\
\hline Format & 7 & 8 \\
\hline Kebahasaan & 19 & 24 \\
\hline Kegrafisan & 11 & 12 \\
\hline \multicolumn{1}{c}{ Persentase } & 86 & 96 \\
\hline
\end{tabular}

Kepraktisan bahan ajar diberikan juga kepada 10 orang mahasiswa dan terbatas pada aspek keterbacaan bahan ajar. Hasil komentar dan saran dari mahasiswa dapat digunakan untuk perbaikan. Kepraktisan dari penilaian dan respons mahasiswa beserta saran yang diberikan ditunjukkan pada tabel 4 .

Tabel 4. Penilaian Kepraktisan Bahan Ajar oleh Mahasiswa

\begin{tabular}{|c|c|c|}
\hline Responden & Nilai & Komentar dan Saran \\
\hline 1 & 95,00 & $\begin{array}{l}\text { Bahan ajar sudah bagus, kertas yang dipakai untuk bahan ajar alangkah lebih baik apabila menggunakan kertas } \\
\text { majalah }\end{array}$ \\
\hline 2 & 86,66 & $\begin{array}{l}\text { Buku ajar berisi materi yang bagus dan tidak membuat mengantuk sehingga ingin terus membaca sampai selesai } \\
\text { namun ada beberapa bagian yang salah ketik }\end{array}$ \\
\hline 3 & 90,00 & $\begin{array}{l}\text { Bahan ajar yang disusun baik berupa isi, tampilan dan faktor pendukung pemahaman seperti penggunaan gambar } \\
\text { telah bagus dan layak untuk dibelajarkan }\end{array}$ \\
\hline 4 & 85,00 & $\begin{array}{l}\text { Penulisan bahan ajar sudah bagus, warna cover dan desain isi menarik dan mudah untuk dipahami sehingga } \\
\text { mempermudah pembelajaran }\end{array}$ \\
\hline 5 & 98.33 & Materi pembelajaran mudah dipahami dan penggunaan literatur cukup banyak dan jelas \\
\hline 6 & 93.33 & $\begin{array}{l}\text { Secara keseluruhan sudah bagus dan deskripsi materi sangat memudahkan untuk dapat digunakan sebagai bahan } \\
\text { pembelajaran }\end{array}$ \\
\hline 7 & 96.66 & Materi bahan ajar sangat menarik, penyajian isi dan gambar membuat membaca tidak membosankan \\
\hline 8 & 98,30 & Bahan ajar bagus dan menarik untuk digunakan, kesalahan ketik dalam bahan ajar dapat diperbaiki \\
\hline 9 & 95,00 & Saran saja, bahan ajar bisa dialihbahasakan dan dijadikan bilingual \\
\hline 10 & 93,33 & Bisa ditambahkan punggung buku dan memperbanyak gambar pendukung \\
\hline $\begin{array}{c}\text { Rerata } \\
\text { Persentase }\end{array}$ & $16 \%$ & \\
\hline
\end{tabular}

\section{PEMBAHASAN}

Bahan ajar berbasis masalah dikembangkan untuk dapat digunakan sebagai bahan pendukung perkuliahan dengan materi pengelolaan spesies asing invasif Acacia Nilotica di Taman Nasional Baluran. Bahan ajar mutlak diperlukan karena berpengaruh terhadap kualitas pembelajaran (Arsanti, 2018). Bahan ajar Problem Based Learning memiliki kelebihan untuk dapat digunakan dalam pembelajaran. Bahan ajar Problem Based Learning memiliki kelebihan yaitu bagi dosen dan mahasiswa untuk dapat digunakan bersama dalam menganalisis masalah berdasarkan situasi nyata dan kompleks (Simone, 2014). Bahan ajar PBL tepat apabila dikembangkan untuk pembelajaran yang membahas permasalahan nyata dan kompleks seperti permasalahan yang disebabkan invasi Acacia Nilotica.

Hasil validasi bahan ajar dari ahli materi mendapatkan nilai 95,58\% hal ini berarti bahan ajar telah sangat valid namun tetap memerlukan sedikit revisi. Perbaikan bahan ajar bertujuan agar materi yang dipelajari lebih bermakna dan sistematis. Materi bahan ajar hendaknya disusun dengan sistematis mulai dari materi sederhana menuju materi yang lebih kompleks (Salim, 2016), yang sesuai dengan saran dan komentar untuk menambahkan asal kata spesies asing invasif berdasarkan pendapat dari ahli dan diletakkan di awal pembelajaran yang bertujuan agar mahasiswa mengerti yang dimaksud dengan spesies asing invasif. Pemilihan materi ajar berkaitan dengan strategi dan pemilihan media ajar. Pemahaman karakteristik materi ajar sangat penting karena berkaitan dengan strategi pembelajaran, penentuan pengalaman mahasiswa dalam belajar, penggunaan media pembelajaran dan penilaian hasil belajar (Sudarisman, 2015).

Validasi bahan ajar dari ahli media dan pengembangan bahan ajar mendapatkan nilai 90,52\% yang berarti bahan ajar telah sangat valid, namun tetap memerlukan sedikit revisi. Validator ahli media membantu memvalidasi ketepatan dalam merancang bahan ajar (Suparti et al., 2015), sehingga apabila terdapat bagian dari bahan ajar yang kurang tepat dapat diperbaiki kembali. Validator ahli media juga menilai bahan ajar dalam bentuk ukuran fisik, cetakan, ukuran huruf, warna, ilustrasi dan ketepatan komponen. Bahan ajar yang dikemas dengan baik membuat pembaca tertarik untuk membaca dan mempelajari lebih jauh (Oktaviana et al., 2015). Bahan ajar juga harus memiliki komponen lengkap untuk mencapai tujuan pembelajaran (Lestari, 2013; Prastowo, 2015) dan contoh soal serta cara menjawab (Mbulu \& Suhartono, 2004). Media pembelajaran adalah salah satu cara untuk mendukung proses pembelajaran. Media pembelajaran digunakan untuk memperjelas penyajian informasi, 
memberikan pengalaman belajar, memberikan motivasi belajar, serta mengatasi keterbatasan indera, ruang dan waktu (Ariyanto et al., 2018). Bahan ajar yang didesain dengan baik dapat dipakai untuk melatih kebenaran dalam berpikir, sistematis, analisis, kritis, dan kreatif (Salim, 2016).

Penilaian bahan ajar dari praktisi telah sangat praktis untuk digunakan yang memberikan penilaian 89,58\%. Bahan ajar yang telah sangat praktis dapat digunakan oleh mahasiswa untuk lebih efektif dan efisien (Sunismi \& Fathani, 2016). Komentar dan saran yang diberikan oleh praktisi lapangan yaitu menambahkan pertanyaan dalam bahan ajar ke tahapan analisis agar mahasiswa mampu menganalisis suatu permasalahan dan berlatih menyelesaikan masalah. Pertanyaan yang dimuat dalam bahan berpengaruh terhadap keaktifan mahasiswa (Nugraha et al., 2013). Bahan ajar yang memuat contoh soal dan cara menjawab yang tepat diharapkan dapat membantu mahasiswa untuk lebih aktif dalam belajar dan memecahkan masalah. Bahan ajar yang telah terbukti sangat praktis tetap harus dievaluasi oleh mahasiswa, hal ini bertujuan agar bahan ajar benar-benar dapat dipahami oleh pembaca (Mbulu \& Suhartono, 2004). Penilaian dari mahasiswa terkait bahan ajar mendapatkan nilai 93,16\% yang berarti bahan ajar telah sangat praktis.

\section{SIMPULAN}

Bahan ajar berbasis Problem Based Learning yang dikembangkan dari hasil penelitian persebaran spesies asing invasif Acacia nilotica di Taman Nasional Baluran sangat valid dengan nilai validitas berdasarkan penilaian dari ahli materi sebesar 95,58\% dan ahli media sebesar 90,52\%. Nilai kepraktisan bahan ajar berdasarkan penilaian yang diberikan praktisi lapangan sebesar 89,58\% dan penilaian oleh mahasiswa sebesar 93,16\% yang masuk kategori sangat praktis. Bahan ajar Problem Based Learning yang telah valid dan sangat praktis dapat dilanjutkan untuk mengetahui keefektifannya dengan mengukur variabel tertentu.

\section{DAFTAR RUJUKAN}

Ariyanto, A., Priyayi, D. F. \& Dewi, L. (2018). Penggunaan Media Pembelajaran Biologi di Sekolah Swasta Salatiga. Bioedukasi: Jurnal Pendidikan Biologi, 9(1), 1-13. DOI: http://dx.doi.org/10.24127/bioedukasi.v9i1.1377

Arsanti, M. (2018). Pengembangan Bahan Ajar Matakuliah Penulisan Kreatif Bermuatan Nilai-Nilai Pendidikan Karakter Religius bagi Mahasiswa Prodi PBSI, FKIP, Unisula. Kredo: Jurnal Ilmiah Bahasa dan Sastra, 1(2), 71—90. DOI: https://doi.org/10.24176/kredo.v1i2.2107

Branch, R. M. (2018). Instructional Design: The ADDIE Approach. New York: Springer.

Caesariantika, E., Kondo, T., \& Nakagoshi, N. (2011). Impact of Acacia Nilotica (L.) Willd, ex Del Invasion on Plant Species Diversity in the Bekol Savanna Baluran National Park, East Java, Indonesia. Tropics, 20(2), 45-53. https://doi.org/10.3759/tropics.20.45

Djufri. (2012). Autoekologi Akasia (Acacia nilotica) (L.) Willd. ex. Del di Taman Nasional Baluran Jawa Timur. Jurnal Biologi Edukasi, 4(1), 46-55.

Euler, D., \& Kuhner, P. (2017). Problem-Based Assignments as a Trigger for Developing Ethical and Reflective Competencies. Interdisciplinary Journal of Problem-Based Learning, 11(2).

Gazali, R.Y. (2016). Pengembangan Bahan Ajar Matematika untuk Siswa berdasarkan Teori Belajar Ausubel. Phytagoras: Jurnal Pendidikan Matematika, 11(2), 182-192. https://doi.org/10.21831/pg.v11i2.10644

Hartati, R. (2016). Peningkatan Aspek Sikap Literasi Sains Siswa SMP melalui Penerapan Model Problem Based Learning pada Pembelajaran IPA Terpadu. Edusains, 8(1), 90-97. https://doi.org/10.15408/es.v8i1.1796

Izzati, N., Hindarto, N., \& Pamelasari, S. D. (2013). Pengembangan Model Tematik dan Inovatif Berkarakter pada Tema Pencemaran Lingkungan untuk Siswa Kelas VII SMP. Jurnal Pendidikan IPA Indonesia, 2(2), 183 - 188.

Lestari, I. (2013). Pengembangan Bahan Ajar Berbasis Kompetensi. (Sesuai dengan Kurikulum Tingkat Satuan Pendidikan). Padang: Akademia Permata.

Lewinsohn, T. M., Attayde, J.L., Fonseca, C.R., Ganade, G., Jorge L., Kollmann, J., Overbeck, G.E., Prado, P.I., Pillar, V.D., Popp, D., Rocha, P. L. B., Silva, W.R., Spiekermann, A. \& Weisser, K.W. (2015). Ecological Literacy and Beyond: Problem-Based Learning for Professionals. AMBIO, 44(2), 154-162. DOI:10.1007/s13280-014-0539-2

Mbulu, J., \& Suhartono. (2004). Pengembangan Bahan Ajar. Malang: Elang Mas.

Moradmand, N., Datta, A. \& Oakley, G. (2014). The Design and Implementation of an Educational Multimedia Software: Using ADDIE to Gui Instructional System Design. The Journal of Applied Instructional Design, 4(1), 37 - 49.

Nugraha, D. A., Binadja, A., \& Supartono. (2013). Pengembangan Bahan Ajar Reaksi Redoks Bervisi SETS, Berorientasi Konstruktivistik. Journal of Innovative Science Education, 2(1), 27-34.

Oktaviana, I., Sumitro, S. B., \& Lestari, U. (2015). Pengembangan Bahan Ajar Berbasis Penelitian Karakterisasi Protein Membran Sperma pada Matakuliah Bioteknologi. Florea: Jurnal Biologi dan Pembelajarannya, 2(2), 33 -42. http://doi.org/10.25273/florea.v2i2.413

Prastowo, A. (2015). Panduan Kreatif Membuat Bahan Ajar Inovatif. Yogyakarta: DIVA Press.

Pratiwi, D., Suratno., \& Pujiastuti. (2014). Pengembangan Bahan Ajar Biologi Berbasis Pendektan SAVI (Somatic, Auditory, Intellectual) pada Pokok Bahasan Sistem Pernapasan Kelas XI SMA dalam Meningkatkan Motivasi dan Hasil Belajar Siswa. Jurnal Edukasi UNEJ, 1(2), 5-9. 
Salim. (2016). Pengembangan Bahan Ajar Matematika Berbantuan Software Drive untuk Meningkatkan Kemampuan Berpikir Kritis Matematis Siswa Kelas X1 IPA SMA Negeri 1 Pasarwajo. Indonesian Digital Journal of Mathematics and Education, 3(4), 199-207.

Simone, C. D. (2014). Problem-Based Learning in Teacher Education: Trajectoreis of Change. International Journal of Humanities and Social Science, 4(12), 17-29.

Sudarisman, S. (2015). Memahami Hakikat dan Karakteristik Pembelajaran Biologi dalam Upaya Menjawab Tantangan Abad 21 serta Optimalisasi Kurikulum 2013. Florea: Jurnal Biologi dan Pembelajarannya, 2(1), 29_35. http://doi.org/10.25273/florea.v2i1.403

Sunismi., \& Fathani, A. H. (2016). Uji Validasi E-Module Matakuliah Kalkulasi untuk Mengoptimalkan Student Centered Learning dan Individual Learning Mahasiswa S-1. Jurnal Review Pembelajaran Matematika, 1(2), $174-191$.

Suparti., Wiryokusumo, I., \& Adiwalujo, D. (2015). Pengembangan Bahan Ajar Ilmu Pengetahuan Alam (Biologi) Berbasis Web dengan Pendekatan Jigsaw untuk Siswa Sekolah Menengah Pertama Kelas VIII. Jurnal Teknologi Pembelajaran Devosi, 5(2), 138-150.

Sutomo., \& Etten, E.V. (2017). Species Distribution Model of Invasive Alien Species Acacia Nilotica for Central-Eastern Indonesia Using Biodiversity Climate Change Virtual Laboratory (VCCVL). Tropical Drylands, 1(1), 36-42. DOI https://doi.org/10.13057/tropdrylands/t010106

Wahyudi, H.A., Kurniawati, D. A. Supriyanto., \& Sutadi. (2016). Habitat Overlap Between Banteng (Bos Javanicus Javanicus) and Domestic Cattle in Baluran National Park, East Java. Journal of Indonesian Natural History, 4(4), 41-46.

Wulandari, N. \& Sholihin, H. (2015). Penerapan Model Problem Based Learning (PBL) pada Pembelajaran IPA Terpadu untuk Meningkatkan Aspek Sikap Literasi Sains Siswa SMP. Prosiding Simposium Nasional Inovasi dan Pembelajaran Sains 2015, 8 dan 9 Juni 2015. Bandung.

Yusuf, M. M., Amin, M., \& Nugrahaningsih. (2017). Developing of Instructional Media-Based Animation Video on Enzyme and Metabolism Material in Senior High School. Indonesian Journal of Biology Education, 3(3), 254 -257. 